\title{
Transnational Education: Looking at Out- and Inflow of International Student Migration
}

\author{
Ika Sandra \\ Sociology of Education Department, Uppsala University, Sweden \\ ika.langit@gmail.com
}

\begin{abstract}
The interest of students from various countries to study overseas have been increasing lately, resulting in a global trend. Their reasons could be different from one another. This study analysed student migration using different models and theories. Through qualitative research, using literary and ethnographic analysis along with transnational perspectives, this project analyzed the reasons behind student's migration. The finding indicates that different theories and approaches show different reasons why the students migrate. Push-pull factor theory shows that factors from the home country and the host country can count as reasons for why students study abroad. World system theory shows how economically, politically, and socially powerful countries play an important role in attracting international students. The demand and supply models are related to the middle class who are eager to gain cultural and social capital through studying abroad. Finally, the global space approach has three poles to look at international student flows; one of which is the Pacific pole where English-speaking countries become popular destinations particularly among international students from Asian countries. This article suggests that if host countries want to market their education comprehensively, the host countries should give more space and easy access for the home countries of the outflows of student migration.
\end{abstract}

Keywords: student migration, transnational education, Asian student migration

\begin{abstract}
ABSTRAK
Ketertarikan pelajar dari berbagai negara untuk melanjutkan pendidikan di luar negeri semakin meningkat belakangan ini, sehingga menjadi sebuah tren global. Alasan mereka untuk belajar di luar negeri bisa berbeda satu sama lain. Kajian ini menganalisis migrasi pelajar menggunakan beberapa model dan teori berbeda. Melalui penelitian kualitatif, dengan menggunakan studi literatur dan analisis etnografis serta perspektif transnasional, kajian ini menganalisis berbagai alasan para pelajar pergi ke luar negeri. Hasil kajian menunjukkan bahwa teori dan pendekatan yang berbeda-beda menunjukkan alasan migrasi yang berbeda. Teori faktor pendorong-penarik (push-pull) menunjukkan bahwa faktor pendorong dari negara asal dan faktor penarik dari negara tuan rumah bisa dijadikan alasan pelajar bersekolah ke luar negeri. Teori sistem dunia (world system theory) menunjukkan bagaimana negara-negara yang kuat dalam posisi ekonomi, politik, dan sosial mempunyai peran penting dalam menarik pelajar asing. Model penawaran dan permintaan berkaitan dengan kelas menengah yang sangat ingin mendapatkan modal kultural dan sosial melalui belajar di luar negeri. Terakhir, pendekatan ruang global menunjukkan tiga area fokus perhatian dalam migrasi pelajar internasional, salah satunya yaitu kawasan Pasifik di mana negara-negara berbahasa Inggrisnya menjadi tujuan populer terutama bagi pelajar dari negara-negara Asia. Saran untuk ke depannya, apabila negara-negara tuan rumah ingin memasarkan sekolahsekolah mereka secara komprehensif, negara-negara tujuan ini harus memberikan ruang dan akses yang mudah bagi negara-negara pengirim pelajar internasional.
\end{abstract}

Kata kunci: migrasi pelajar, pendidikan transnasional, migrasi pelajar Asia 


\section{INTRODUCTION}

Nowadays, studying abroad is becoming popular among students around the world. However, the reasons why each student studies abroad can be different. For those who come from Asia and Africa, the need for better access to education often becomes a reason to move abroad. Another reason can be the programs that are offered by foreign universities that are not offered in the home country. Historical relations, languages and geographical proximities between the home and host coutntries are also the reason to get a degree abroad (Marginson, 2006). Another reason for studying abroad is to achieve a better future through acquiring different skills and diverse experience.

Some graduates - after gaining experience and global insight from abroadare expected to be able to bring benefits on their return to their home countries, particularly students from developing countries. For example, in Malaysia, employers give a particularly high status to graduates from foreign universities, so they will get a job more easily. Therefore, many students migrate from their country to another country to attend international educational programs with the hope of gaining a better quality education as well as a great experience during their program and get better opportunities once they return home (Brooks \& Waters, 2011).

Furthermore, student migration is also important to some countries to establish international relations and open the free market through cooperations with universities in some other countries. In Indonesia for instance, many top universities from other countries have their representatives in some cities in Indonesia; they come to help parents and students and give more information about the countries and universities directly. This attracts students to go to some universities abroad because they find that the representatives are extremely helpful. Other embassies and cultural centers also hold interesting activities and events to attract potential students, for example the US embassy sponsored free GRE preparation courses and give away GRE test vouchers.

To understand international student migration, there are several models to help explain the flow of international students, and this article will focus on four models. In this article, the case study is the Indonesian students who study abroad. Based on UNESCO Institute for Statistics (UIS) data, 47,574 Indonesians study abroad for tertiary studies in 2017, a consistently increasing number since 2013, which is 39,448 . The most popular destination is Australia, reaching 11,040, possibly because Australia is the closet Western country to Indonesia. In Malaysia, a neighboring country with almost similar culture and language as Indonesia, 10,401 Indonesian students study there in 2017. In the United States and the United Kingdom, homes to top universities in the global rank, the numbers of Indonesian students are 8,782 and 3,620 respectively. 3,616 Indonesians study in Japan, which has a historical link with Indonesia, which can be a reason behind Japan's popularity. Indonesian students in Germany reached 2,394 in 2017. Many Indonesian 
students study in Germany to become engineers because engineering programs in Germany are seen to have a higher quality than in Indonesia. In Saudi Arabia 1,715 Indonesian students in 2017 went to universities there; many of them took religion studies probably due to the two holy cities for muslim countries (UNESCO, 2019). One possible reason for the increasing number is the full scholarship provided by the Indonesian government for outstanding students which started in 2013. Meanwhile, in 2018, 7,677 international students come to study in Indonesia, a significant fewer number than the outflow migration number, as Indonesia has only started applying online student visa for international students since 2014 (UNESCO, 2019, Kemenristek/BRIN, 2017).

\section{RESEARCH METHOD}

This qualitative study was conducted using literary analysis and ethnography. Qualitative method works better in answering the research questions by describing the results with narratives instead of numbers. Ethnography as a research method tends to be holistic, addressing a lot of theories that are related to culture, subculture, and social activities (Fetterman, 2019). The characteristics of ethnography are more focused on history of the group, the geography of the location, kinship patterns, symbols, politics, economic systems, educational or socialization systems, and the degree of contact between the target culture and the mainstream culture (Fetterman, 2019). The ethnographic approach is necessary to explore the workings of culture in the classroom, school and administrative system, and it should not limit researchers mainly to phenomenological approaches or to the focus of only the subjective experience of the participants (Fetterman, 2019). Using ethnographic observation to gather data has helped in obtaining detailed information that might not be achieved through interview or other kinds methods. Therefore, it provides a more specific information about the object which is being observed (Mikael Palme, 2018). Furthermore, there are two types of observation in ethnography, they are closed observation and open observation. The former is more focused on certain topics observed. Mostly, the topics are influenced by previous research or theoretical perspectives. The latter has more general topics being observed by using more general research questions (Mikael Palme, 2018).

\section{RESULTS AND DISCUSSION}

Different models, theories, and traditions reveal different reasons for international student migration. The discussion below shows analysis using pushpull model, world system theory, supply and demand model, and global space model.

\section{Push-Pull Model}

According to the push-pull factor model, there are several reasons that can explain student migration flows to destination countries. To begin with, a push factor is something that makes a student want to leave their country and go abroad for studying. This is possible, for example, because of the a of quality of education in the home country, a lack of opportunities in terms of careers, or because students are looking for educational programs that are unavailable in their home country 
(Mazzarol \& Soutar, 2002). On the other hand, a pull factor can be understood as something that the host countries can offer international students; for instance, better education system, highly ranked degree programs, cultural diversity, and others (Mazzarol \& Soutar, 2002). There are three steps international students take in deciding to choose the subjects to study abroad. First, the students must have the desire to study in overseas universities instead of universities in their home countries that can be influenced by the push factors within the countries. Second, after deciding to study abroad, the students have to decide which country they want to go, which depends on the pull factor from a certain country that they find it more attractive than others. Last, if a student has chosen a country, they will have to select which university in a country they will take part; this is also influenced by the pull factor where the quality of a university is measured in many aspects (Mazzarol \& Soutar, 2002).

In this article, international students from Indonesia is applied as the case study. They take degree programs in overseas universities because they see universities abroad have better quality compared to universities in home countries, which can be a push factor. Some of them are interested in understanding Western cultures better, which can be seen from the statistic above where Western countries like Australia and the US are popular destinations for Indonesian students. Furthermore, from the pull factor perspective, the easy access to education facilities in overseas universities such as academic journals, research and internet access - the things that are quite limited in Indonesia-attract the students to study abroad. Another pull factor is the good ranks of overseas universities in global scale which is seen as a better opportunity for Indonesian students to improve their future career. Moreover, some Indonesian students go to Japan to study, as the historical link between Indonesia and Japan could be a reason that makes some Indonesian students to study in Japan. Meanwhile, geographical proximity becomes a reason Indonesian students go to Malaysia, which can be easy for them to adapt with since both countries share the same language and culture. However, there are fewer international students come to Indonesia since Indonesian universities do not have a good rank in the global scale.

\section{World System Theory}

Besides push-pull factors, world system theory offers another understanding to international student migration. Powerful countries in economic, political and social positions play an important role in attracting international students. The good reputation of a country within the world system is a reason for students to move to the country. This includes powerful countries like the US. Other Western countries are the center for student migration destitation (Gorgoshidze, 2010). There are three components in world system theory; they are the core, periphery, and semiperiphery. The core produces high technology processed goods to be exported to the periphery and semi-periphery. Most of the countries in the core is Western industrialized countries such as the UK, Germany, the US, France and Canada. Peripheral countries have a function to produce and export low technology processed goods for both the core and semi-periphery. The countries within this 
periphery are the former British colonies and French colonies such as African countries. Meanwhile countries in the semi-periphery do the same activities like in the core and the periphery such as Asian and East European countries (Chen \& Barnett, 2000).

In the case of the Indonesian student migration, the core countries like the US and some European countries like Germany and the UK become popular destinations for them. This is because they think that studying in core countries can enhance their future career. Hence, to become a student in some universities in the core countries could be the goal for Indonesian students. However, developing countries like Indonesia-when they send their students to study abroad, particularly to the core countries, with the hope that the students will come back with more experiences to develop their home country-have the risk of not seeing the students returning home. As a result, more than 8 million professional Indonesians work and prefer staying abroad (Moerti, 2014). This is because developed countries like the European countries, the US, Australia, and Singapore offer more opportunities in terms of jobs and high salaries. It will feel different when they come back to Indonesia, which is a periphery country that have limited job vacancies, a lack of infrastructures and low salaries. In this way, they prefer to be citizens of Western countries, with the many opportunities that they will have (Moerti, 2014). Indonesia's being part of the periphery due to lacking quality education and having low-skilled workers also results in Indonesia's inability to attract many international students.

\section{Supply and Demand Models}

Supply and demand models offer another way to analyze international student migration. Demand in the context of student migration is an effect of the middle class who gets interested in studying abroad for the purpose of gaining cultural capital and social capital within Western culture (Findlay, 2011). This is also because of the awareness about the future career that they can gain after. In the context of supply from foreign universities and host countries, the purpose is the financial interest by organizing, supplying, and marketing higher education which influences international student migration in the global economy aspect. Furthermore, selling international degrees to international students also benefits those involved in the process. The suppliers will gain financial capital and cultural capital that comes from the home countries of the international students (Findlay, 2011). Cultural capital is especially gained by the suppliers if a number of students continue to stay in the host country after graduation (Findlay, 2011).

From this theory we can understand Indonesian student flows. First, from the demand models, studying overseas becomes popular in Indonesia since 2013 because the Indonesian government established the Finance Ministry's endowment fund for education (LPDP) to give scholarships for the best Indonesian students. Since then, many students from the middle-class families are eager to fight to get the scholarships and have the opportunities to study in overseas universities since everyone can try to apply for them. Through the scholarship opportunities, students from the middle class can get social capital and cultural capital from Western 
countries. Second, from the supply perspective, some countries provide facilities for university representatives to reach potential students such as the International Development Program (IDP) from Australia's education organizations and the British Council from the UK. This is a way some universities and host countries attract Indonesian students to choose their universities since they also need international students from Indonesia to take advantage of the students' financial capital and cultural capital. On the other hand, there is still few demands from international students to study in Indonesia. Most international students in Indonesia come from countries like Australia and Japan who want to learn about Indonesian cultures.

\section{Global Space of International Students}

The global space of international students is a model that shows specific international student flow for the countries of destination by laying out the structure of the countries of destination as well as countries of origin by using correspondence analysis (Börjesson, 2017). This analysis has a three-pole structure, which includes a Pacific pole, a central European pole and a French/Iberian pole, where each pole represents different ways of international student recruitment in the global space in order to explain international student flows. The Pacific pole represents the popular countries hosting international students. The host countries in the Pacific pole are favorite places where international students tend to study like the US, Australia and Japan, while the home country of most students who study in the Pacific pole is China (Börjesson, 2017). The second pole is the central European which represents the central destination countries for international students from other European countries (neighboring). In this pole, the geographical proximity becomes the main reason for international students to choose host countries for studying. The last pole is the French/Iberian where colonial history becomes a reason for students to have an educational experience in their former colonizer country (Börjesson, 2017). For example, students come from African, Latin American, and Caribbean countries.

In order to have a better understanding of the concept of the global space of international students, one also needs to understand the aspect of language. In the Pacific pole, English-speaking countries become the priority of international student to pursue their goals (Börjesson, 2017). One of the reasons is that studying in English-speaking countries can help them to learn and to become more fluent in English, as most of the students come from Asian countries. This also makes the students communicate easily with people around the world as English is known as an international language or the lingua franca. For the central European pole, countries who speak German and Slavic languages become the popular destinations for international students within European countries. For the last pole, which is the French/Iberian pole, the international students are determined by colonial languages like French, Spanish and Portuguese (Börjesson, 2017).

For the Indonesian student migration, we can start by identifying Indonesia as part of the Asian countries. Some Indonesian students use language of the host country as a reason for deciding their destination. Hence, English-speaking countries are popular among Indonesian students such as the US, the UK, and Australia. 
English is popular among Indonesian students because English subject is a part of the Indonesian curriculum since junior high schools. Moreover, this is efficient for Indonesian students because when they apply for the government scholarship, English is one of the requirements, so they do not have to learn another language when they are abroad. Another popular destination in the Pacific for Indonesian students is Japan. Indonesia was colonized by Japan. Beside that, its universities have good reputations in science programs, therefore some of scientists from Indonesia study in Japan. According to this global space model, there are few students who come to Indonesia to get their degrees, as Indonesia is a country of origin which sends many students to study at overseas universities.

\section{CONCLUSION}

From the explanation above, we can see different theories and approaches that can explain international student migration. The push-pull factor theory shows that factors from the home countries and host countries are the reason students study abroad, such as the quality of universities, the culture of the host countries, as well as historical links and geographical proximity between home and host countries. World system theory shows how powerful countries in economic, political and social positions play an important role in attracting international students, particularly countries that are in core positions such as the US and other Western industrialized countries. The demand and supply models reveal the middle class' demand to gain cultural capital and social capital through studying abroad as well as the top universities' supply to have economic interests from the international students. Last, the global space approach has three poles to focus on international student flows, one of which is the Pacific pole where English-speaking countries become popular destinations particularly to international students from Asian countries.

\section{REFERENCES}

Börjesson, M. (2017). The global space of international students in 2010. Journal of Ethnic and Migration Studies. https:/ / doi.org/10.1080/1369183X.2017.1300228

Brooks, R., \& Waters, J. (2011). Student mobilities, migration and the internationalization of higher education. In Student Mobilities, Migration and the Internationalization of Higher Education. https:/ / doi.org/10.1057/9780230305588

Chen, T.-M., \& Barnett, G. A. (2000). Research on international student flows from a macro perspective: A network analysis of 1985, 1989 and 1995. Higher Education, 39(4), 435-453.

Fetterman, D. M. (2019). Ethnography: Step-by-step (Vol. 17). SAGE Publications, Incorporated.

Findlay, A. M. (2011). An Assessment of Supply and Demand-side Theorizations of International Student Mobility. International Migration. https:/ / doi.org/10.1111/j.1468-2435.2010.00643.x

Gorgoshidze, K. (2010). Understanding motivations for student mobility: The case of Georgia. 
Kemenristek-BRIN. (2017). Perguruan Tinggi Indonesia Diminati Mahasiswa Asing. Highlight: 12 May 2017. https://www.ristekbrin.go.id/siaranpers/perguruan-tinggi-indonesia-diminati-mahasiswa-asing-2/

Marginson, S. (2006). Dynamics of national and global competition in higher education. In Higher Education. https:/ / doi.org/10.1007/s10734-004-7649-x

Mazzarol, T., \& Soutar, G. N. (2002). "Push-pull” factors influencing international student destination choice. International Journal of Educational Management.

Mikael Palme. (2018). Ethnographic methods: observation. No Publication.

Moerti, W. (2014). 5 Fakta seputar insinyur Indonesia pilih kabur ke luar negeri. https:// www.merdeka.com/uang/5-fakta-seputar-insinyur-indonesia-pilihkabur-ke-luar-negeri.html

UNESCO. (2019). International student mobility in tertiary education in Indonesia. http://data.uis.unesco.org/ 